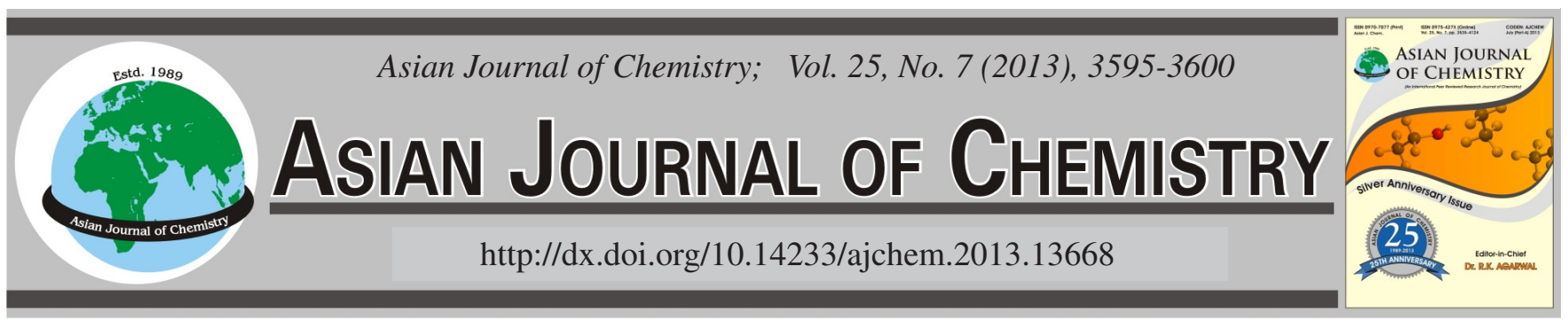

\title{
Degradation of the Emerging Contaminant Naproxen in Aqueous Solutions by Dielectric Barrier Discharge
}

\author{
J.Q. WANG ${ }^{1}$, B.G. ZHENG ${ }^{1}$, J.B. ZHANG ${ }^{2, *}$ and Z. ZHENG ${ }^{2, *}$
}

${ }^{1}$ State Key Laboratory of Pollution Control and Resource Reuse, School of the Environment, Nanjing University, Nanjing, P.R. China ${ }^{2}$ Department of Environmental Science and Engineering, Fudan University, Shanghai, P.R. China

*Corresponding authors: Tel/Fax: +86 21 65643342; +86 21 65642192; E-mail: zzhenghj@fudan.edu.cn; jbzhang@ fudan.edu.cn

\begin{abstract}
This study focused on the degradation of naproxen by dielectric barrier discharge. The effects of various parameters such as output power, naproxen initial concentration, solution $\mathrm{pH}$, presence of additives on the degradation of naproxen were investigated. The degradation value was $93.2 \%$ when output power was $60 \mathrm{~W}$ and $6 \mathrm{~min}$ was selected as the discharge time. The degradation efficiency was higher under acidic conditions than in alkaline media and the degradation efficiency decreased with the increasing of initial concentration at the same discharge time. $0.25 \% \mathrm{H}_{2} \mathrm{O}_{2}$ additive enhanced the degradation process, however, 1.0 and $1.5 \% \mathrm{H}_{2} \mathrm{O}_{2}$ additive hindered the degradation. The presence of $\mathrm{Fe}^{2+}$ could enhance the degradation of naproxen, however, the increment in degradation efficiency might be suppressed to some extent at a high concentration level. Identification of byproducts has shown that demethylation and decarboxylation are the principal initial processes in the degradation of naproxen under the conditions of this experiment.
\end{abstract}

Key Words: Degradation, Naproxen, Dielectric barrier discharge.

\section{INTRODUCTION}

In recent years, the pharmaceutical pollutants in the environment have received much attention due to their unknown environmental impacts and their possible damage to botany ${ }^{1,2}$. These compounds and their metabolites can reach sewage systems, where they are not easily degraded under the typical biological treatments in the municipal wastewater treatment plants ${ }^{3-6}$. Naproxen and naproxen-based products are pharmaceutical pollutants and have been detected in surface water, groundwater, wastewater and even in drinking water in the range from $n g \mathrm{~L}^{-1}$ to several $\mu \mathrm{g} \mathrm{L}^{-17-10}$. Their presence has been observed due to their adverse effects on biota such as reducing the lipid peroxidation system of bivalves ${ }^{11}$, so it is becoming a serious problem.

A lot of research has been carried out to remove naproxen with ozonation, free chlorine, phototransformation and $\mathrm{H}_{2} \mathrm{O}_{2} /$ UV. These treatments usually achieve high removal efficiencies of naproxen, but the mineralization efficiencies of naproxen are not high ${ }^{12-15}$. The degradation of naproxen in biological ways has also been tested, the research results show that the white-rot fungus Trametes vesicolor can degrade naproxen in liquid medium and sewage sludge $e^{3,8,16}$. When naproxen initial concentration is $55 \mu \mathrm{g} \mathrm{L}^{-1}$ in liquid medium, which is the typical level in the environment, the degradation efficiency is $95 \%$ after $5 \mathrm{~h}$ by white-rot fungus Trametes vesicolor ${ }^{8}$. In five different wastewater treatment systems, including constructed wetland system, sand filter system and activated sludge system, the enantioselective degradation of naproxen is feasible under aerobic and anaerobic conditions.

Nowadays, dielectric barrier discharge (DBD) is widely used in environmental protection field. It is an excellent source for producing ideal energetic electrons with 1-10 eV and high density ${ }^{17}$. In humid air dielectric barrier discharge could produce UV light and many reactive species such as free electrons, negative ions, positive ions, uncharged short-lived radicals, $\mathrm{H}_{2} \mathrm{O}_{2}$ and $\mathrm{O}_{3}$. The detailed mechanisms are as follows (eqns. 1-10) $)^{18-21}$. This technology that integrates light, electronic and chemical oxida-tion into one process has a collective effect on degrading organic species.

$$
\begin{aligned}
& \mathrm{O}_{2} \stackrel{\mathrm{e}^{-}}{\longrightarrow} \mathrm{O}^{\bullet}+\mathrm{O}^{\bullet} \\
& \mathrm{O}^{\bullet}+\mathrm{O}_{2} \longrightarrow \mathrm{O}_{3} \\
& \mathrm{O}^{\bullet}+\mathrm{H}_{2} \mathrm{O} \longrightarrow{ }^{\circ} \mathrm{OH}+{ }^{\bullet} \mathrm{OH} \\
& \mathrm{O}^{-}+\mathrm{H}_{2} \mathrm{O} \longrightarrow{ }^{\circ} \mathrm{OH}+\mathrm{OH}^{-} \\
& \mathrm{O}^{-}+\mathrm{H}_{2} \mathrm{O} \longrightarrow \mathrm{HO}^{\circ}+\mathrm{OH}^{-} \\
& 2 \mathrm{H}_{2} \mathrm{O} \mathrm{e}^{-} 2_{2} \mathrm{O}_{2}+\mathrm{H}_{2} \\
& \mathrm{O}_{3}+\mathrm{H}_{2} \mathrm{O}_{2} \longrightarrow{ }^{\bullet} \mathrm{OH}+\mathrm{O}_{2}+\mathrm{HO}_{2}^{\cdot} \\
& \mathrm{O}_{3}+\mathrm{HO}_{2} \longrightarrow{ }^{\bullet} \mathrm{OH}+\mathrm{O}_{2}+\mathrm{O}_{2}^{-}
\end{aligned}
$$




$$
\begin{aligned}
& \mathrm{O}_{3}+\mathrm{H}_{2} \mathrm{O} \stackrel{\mathrm{hv}}{\longrightarrow} \mathrm{H}_{2} \mathrm{O}_{2}+\mathrm{O}_{2} \\
& \mathrm{H}_{2} \mathrm{O}_{2} \stackrel{\mathrm{hv}}{\longrightarrow} \mathrm{OH}+{ }^{\circ} \mathrm{OH}
\end{aligned}
$$

The degradation behaviour of naproxen by dielectric barrier discharge has not yet been studied. The purpose of this study was to investigate the possibility of naproxen degradation in aqueous solutions by dielectric barrier discharge and propose the possible degradation mechanism. Factors that might affect the degradation efficiency of naproxen were examined.

\section{EXPERIMENTAL}

Naproxen was purchased from Sigma-Aldrich and its chemical structure is represented in Fig. $1 . \mathrm{CH}_{3} \mathrm{CN}, \mathrm{CH}_{3} \mathrm{COOH}$ and $\mathrm{CH}_{3} \mathrm{OH}$ were obtained from Sigma-Aldrich and HPLC grade. Humic acid was high purity products from SigmaAldrich. The other chemicals were of reagent grade with purity higher than $99 \%$. The ultrapure water was obtained from milliQ system (Elix5+milliQ A10, USA).<smiles>COc1ccc2cc(C(C)C(=O)O)ccc2c1</smiles>

Fig. 1. Chemical structure of naproxen

The experimental apparatus was bought from Nanjing Suman Electronics Co. Ltd., PR China (Fig. 2). It consisted of a reaction cell (DBD-50) and a power supplier (CTP-2000K) that could provide a steady voltage of $100 \mathrm{~V}$. The reaction cell, which was between the high voltage electrode and ground electrode, consisted of two parts. The upper part of the reaction tank was a little bigger than the lower part. The lower part was used to contain the solution, which was $84 \mathrm{~mm}$ in inner diameter, $88 \mathrm{~mm}$ in outer diameter and $6 \mathrm{~mm}$ in height. The reaction tank was put in the center of the two electrodes. The power was supplied by an AC source, which could be operated at an adjustable amplitude voltage. The intensity of discharge in the reaction tank could be denoted by the input power, which was calculated by the average voltage and current of the AC power. The dielectric barrier was made of quartz.

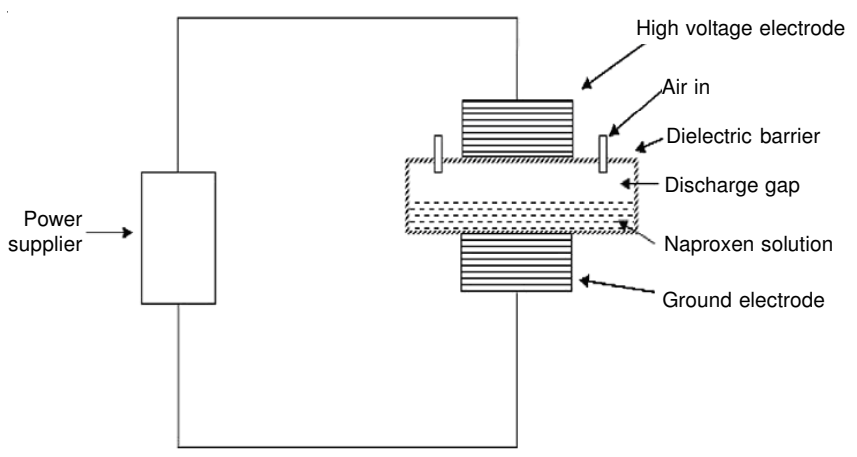

Fig. 2. Scheme of the experimental apparatus

Sample preparation: Naproxen solution at initial concentration of $20 \mathrm{mg} \mathrm{L}^{-1}$ was prepared by solid naproxen with ultrapure water. It was employed to was used to test the effect of output power, $\mathrm{H}_{2} \mathrm{O}_{2}, \mathrm{Fe}^{2+}, \mathrm{NO}_{3}{ }^{-}$, humic acid and initial $\mathrm{pH}$ value on the degradation and to examine the change of $\mathrm{pH}$ value and total organic carbon by DBD. The output power of $60 \mathrm{~W}$ was employed to investigate the effect of naproxen initial concentration, $\mathrm{H}_{2} \mathrm{O}_{2}, \mathrm{Fe}^{2+}, \mathrm{NO}_{3}{ }^{-}$, humic acid and initial $\mathrm{pH}$ value on the degradation and to determine the change of $\mathrm{pH}$ value and TOC by DBD. The $\mathrm{pH}$ value of the solution was adjusted using $\mathrm{HCl}$ dilute solution or $\mathrm{NaOH}$ dilute solution. All the samples were treated at the voltage of $100 \mathrm{~V}$.

Analysis: The concentration of naproxen was determined by using a HPLC system (Agilent, USA, 1200 series highperformance liquid chromatography) equipped with Hypersil ODS HPLC column $(250 \mathrm{~mm} \times 4.6 \mathrm{~mm}$ i.d., $5 \mu \mathrm{m}$, Agilent, USA), a multiple wavelength UV diode array detector and an auto sampler controlling under a chemstation data acquisition system. The mobile phase consisted of $25 \%$ phosphate $(0.01$ mol L ${ }^{-1}$ potassium dihydrogen phosphate, adjusted with phosphoric acid to $\mathrm{pH} 3$ ) and $75 \%$ methanol and the flow rate was $1 \mathrm{~mL} \mathrm{~min}^{-1}$. The determination wavelength was set at 230 $\mathrm{nm}$ and the column temperature was kept at $30^{\circ} \mathrm{C}$.

The degradation efficiency $(\eta)$ of each sample was calculated from the following eqn. 11.

$$
\eta=\frac{\mathrm{C}_{0}-\mathrm{C}_{\mathrm{t}}}{\mathrm{C}_{0}} \times 100 \%
$$

$\eta$ : The degradation efficiency of naproxen (\%); $\mathrm{C}_{\mathrm{t}}$ : The residual concentration of naproxen $\left(\mathrm{mg} \mathrm{L}^{-1}\right) ; \mathrm{C}_{0}$ : The initial concentration of naproxen $\left(\mathrm{mg} \mathrm{L}^{-1}\right)$.

The identification of naproxen and its degradation products resulted from the radiolytic degradation were performed by LC-MS (ThermoQuestLCQ Duo, USA) equipped with Beta Basic- $\mathrm{C}_{18}$ HPLC column $(150 \mathrm{~mm} \times 2.1 \mathrm{~mm}$ i.d., $5 \mu \mathrm{m}$, Finnigan, Thermo, USA). $20 \mu \mathrm{L}$ naproxen solutions treated by DBD were injected automatically into the LC-MS system. The eluent consisted of $65 \%$ of $1.0 \mathrm{mM}$ acetic acid in water and $35 \%$ of acetonitrile. The flow rate was $0.2 \mathrm{~mL} \mathrm{~min}^{-1}$, the other LC conditions were the same as the conditions used in determining naproxen concentration. MS conditions were as follows: the electrospray ionization interface was selected. The capillary temperature was set to $275^{\circ} \mathrm{C}$ with a voltage of 19.00 $\mathrm{V}$. The spray voltage was $5000 \mathrm{~V}$ and the sheath gas flow rate was 18 arb. The spectra were acquired in the negative ion scan mode, over the $\mathrm{m} / \mathrm{z}$ range from $50-600$. All the experiments were repeated twice, the experimental error was below $5 \%$ and the average data were reported.

Total organic carbon (TOC) was determined by TOC analyzer (Shimadzu, TOC-5000A). The $\mathrm{pH}$ value was measured by $\mathrm{pH}$ monitor (Shanghai Kangyi Instrument Co., Ltd. China, PHS-2C).

\section{RESULTS AND DISCUSSION}

Effect of output power on naproxen degradation process: In this work, the DBD was generated over the treated water. Some vapor was generated in the discharging space as the result of exothermic reaction. Thus, the reactive species mentioned in eqns. 1-10 were formed in the DBD reactor. The reactive species produced in the gas phase would be further carried to the water by the gas agitation caused by the ion wind $^{22}$. When these reactive species reached the liquid film, 
the aqueous reactive species would also be produced ${ }^{18}$. There these reactive species would be reactive with organic compounds ${ }^{23}$.

Fig. 3 showed the change of naproxen degradation values with different output powers using DBD. It was indicated that naproxen could be effectively removed from aqueous solutions by DBD. The concentration of naproxen in aqueous solutions decreased with the increasing of output power. When the discharge time was 6 min, 72.8, 93.2 and $96.7 \%$ of naproxen was removed when the output powers were 40,60 and $80 \mathrm{~W}$, respectively. This results show that DBD is an effective method to remove naproxen in aqueous solutions.

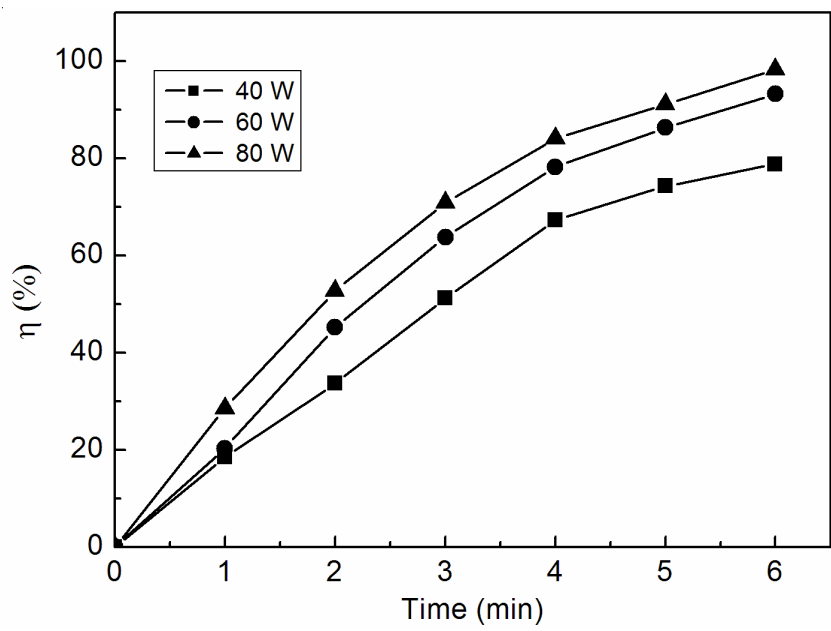

Fig. 3. Change of naproxen degradation values with different output powers $\left(\mathrm{C}_{0}=20 \mathrm{mg} \mathrm{L}^{-1}\right.$, initial $\mathrm{pH}$ value $=6.62$, air flow rate $\left.=0.50 \mathrm{~m}^{3} \mathrm{~h}^{-1}\right)$

Effect of naproxen initial concentration on the degradation process: Fig. 4(a) showed the effect of the initial concentration on naproxen degradation by DBD. As shown in Fig. 4(a), the degradation value decreased with the increasing of initial concentration at the same discharge time. It was indicated that the initial concentration greatly affected naproxen degradation behaviour.

The degradation kinetics of naproxen followed first order kinetics. The change in $\ln \left(\mathrm{C}_{0} / \mathrm{C}_{\mathrm{t}}\right)$ as the discharge time were described in Fig. 4(b). Fig. 4(b) shows a trend and the slope of this plot yielded the first order rate constants. When the initial concentration of naproxen was $10 \mathrm{mg} \mathrm{L}^{-1}$, the rate constant was $0.5552 \mathrm{~min}^{-1}$. However, when the initial concentrations were 20 and $30 \mathrm{mg} \mathrm{L}^{-1}$, the rate constants were 0.4026 and $0.2828 \mathrm{~min}^{-1}$. It showed that rate constants increased with lower initial naproxen concentrations. These experimental results are similar to published findings for the degradation of diuron by dielectric barrier discharge ${ }^{23}$.

Effect of solution $\mathrm{pH}$ on naproxen degradation process: Fig. 5 shows the effect of solution $\mathrm{pH}$ on naproxen degradation efficiency. The results indicated that $\mathrm{pH}$ value is an important factor that affected the naproxen degradation efficiency. The degradation efficiency of naproxen was higher under acidic conditions than in alkaline media. For example, the degradation efficiency of naproxen reached $95.5 \%$ after 4 min of discharge time at $\mathrm{pH}$ value of 3 , whereas the degradation efficiency was only $58.7 \%$ at $\mathrm{pH}$ value of 10 . It is well-known that the major active species, which are useful for the degradation of organic
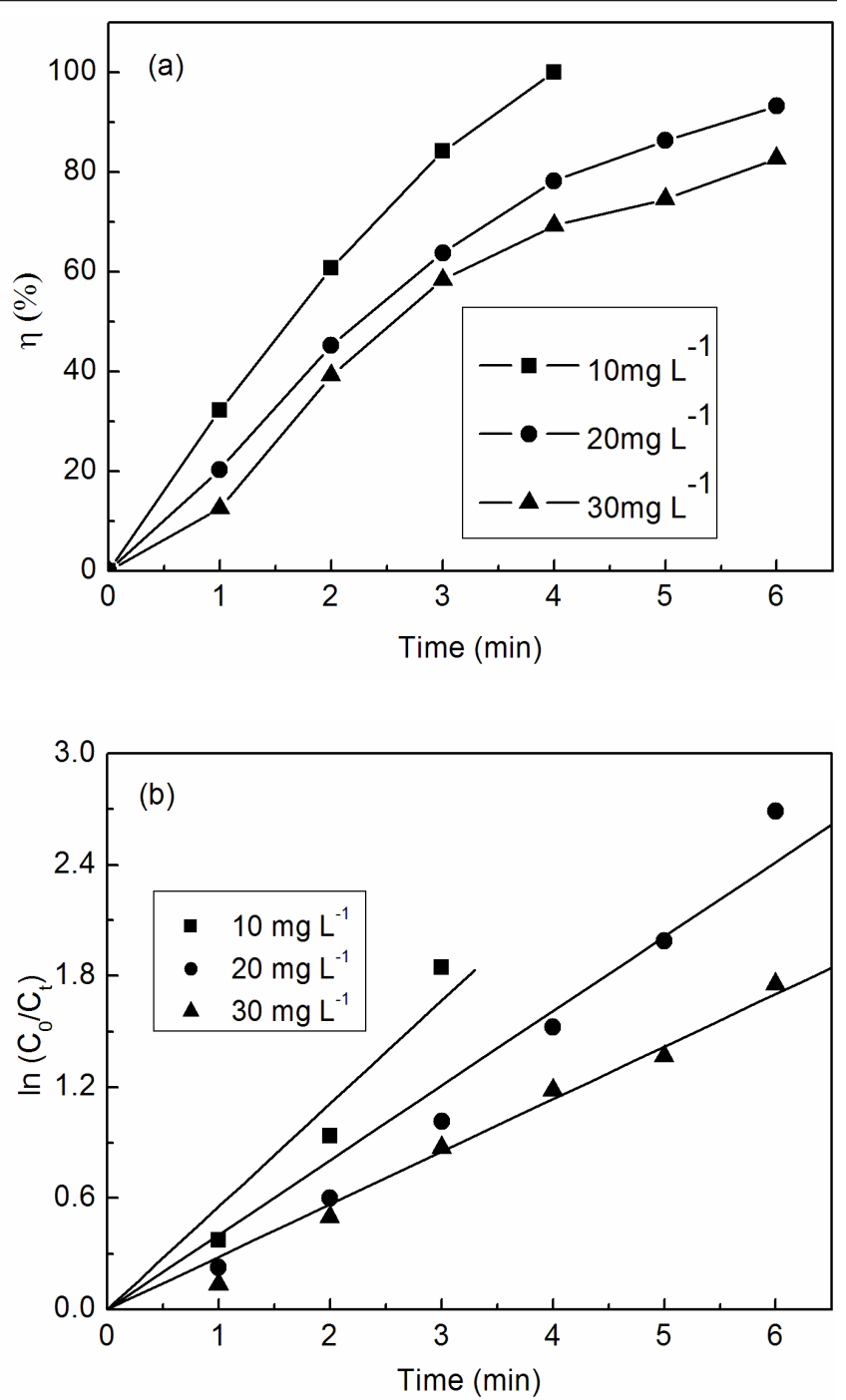

Fig. 4. Effect of the initial concentration on naproxen degradation process (output power $=60 \mathrm{~W}$, initial $\mathrm{pH}$ value $=6.62$, air flow rate $=0.50$ $\left.\mathrm{m}^{3} \mathrm{~h}^{-1}\right)$

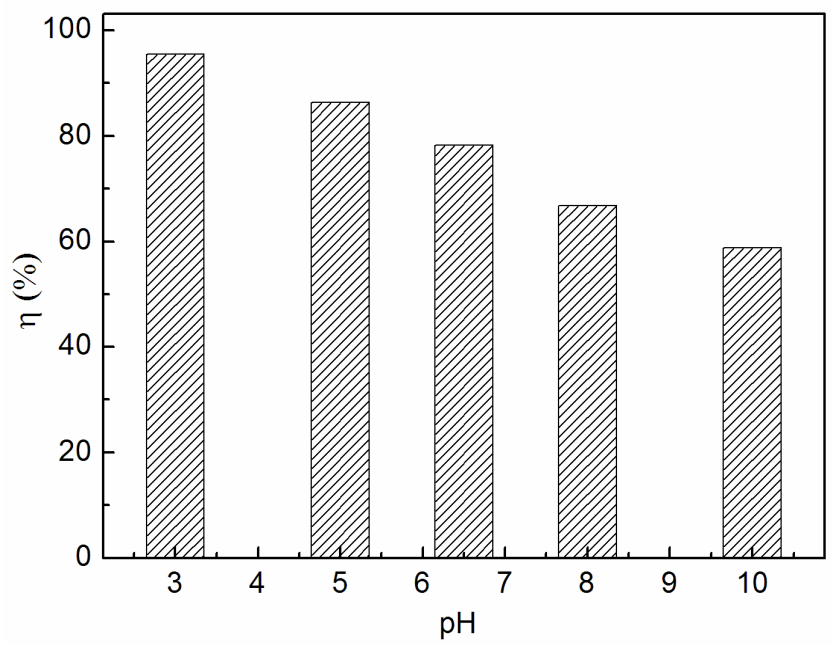

Fig. 5. Effect of the $\mathrm{pH}$ value on naproxen degradation $\left(\mathrm{C}_{0}=20 \mathrm{mg} \mathrm{L}^{-1}\right.$, output power $=60 \mathrm{~W}$, air flow rate $=0.50 \mathrm{~m}^{3} \mathrm{~h}^{-1}$, discharge time $=4$ $\min$ )

pollutants in aqueous solution by pulsed discharge, are ${ }^{\circ} \mathrm{OH}$, $\mathrm{O}_{3}$ and $\mathrm{H}_{2} \mathrm{O}_{2}{ }^{18,24,25}$. Under acidic conditions, more ${ }^{\circ} \mathrm{OH}$ radicals 
were produced and $\mathrm{H}_{2} \mathrm{O}_{2}$ decomposition was inhibited ${ }^{23-25}$, thus the degradation efficiency of naproxen increased. While in alkaline media, $\mathrm{HO}_{2}{ }^{\circ}$ ion would be decomposed by the discharge, which scavenged ${ }^{\circ} \mathrm{OH}$, thus the degradation efficiency of naproxen decreased ${ }^{26}$.

Effect of $\mathrm{H}_{2} \mathrm{O}_{2}$ additive on naproxen degradation process: It is well-known that $\mathrm{H}_{2} \mathrm{O}_{2}$ is ${ }^{\circ} \mathrm{OH}$ radical promoter, it could accelerate the degradation of pollutions in aqueous solutions. In order to test the effect of $\mathrm{H}_{2} \mathrm{O}_{2}$ on naproxen degradation by $\mathrm{DBD}, \mathrm{H}_{2} \mathrm{O}_{2}$ was added at different concentrations of $0.25,1.0$ and $1.5 \%$. The results obtained are shown in Fig. 6. It was indicated that the degradation value in the presence or absence of $\mathrm{H}_{2} \mathrm{O}_{2}$ was improved with the increasing of discharge time and $\mathrm{H}_{2} \mathrm{O}_{2}$ enhanced naproxen degradation at the concentration of $0.25 \%$, however, hindered the degradation at 1.0 and $1.5 \%$. When the discharge time was $6 \mathrm{~min}$ and the concentration of $\mathrm{H}_{2} \mathrm{O}_{2}$ were $0,0.25,1.0$ and $2.0 \%$, the degradation values were 93.2, 94.3, 43.3 and $29.4 \%$, respectively. This result indicated that naproxen degradation by DBD could be enhanced when $\mathrm{H}_{2} \mathrm{O}_{2}$ was added at the appropriate concentration. It might be the reason that when $\mathrm{H}_{2} \mathrm{O}_{2}$ was added at the concentration of $0.25 \%$, $\mathrm{OH}$ was formed by the decomposition of $\mathrm{H}_{2} \mathrm{O}_{2}$ (eqn. 10) ${ }^{27}$ and then ${ }^{\circ} \mathrm{OH}$ concentration increased, so the degradation process enhanced. However, when $\mathrm{H}_{2} \mathrm{O}_{2}$ was added at 1.0 and $1.5 \%$, the hydroxyl radicals generated produced hydroperoxyl radicals $\left(\mathrm{HO}_{2}{ }^{\circ}\right)$ in the presence of a local excess of $\mathrm{H}_{2} \mathrm{O}_{2}$ and then ${ }^{\circ} \mathrm{OH}$ concentration decreased ${ }^{28,29}$.

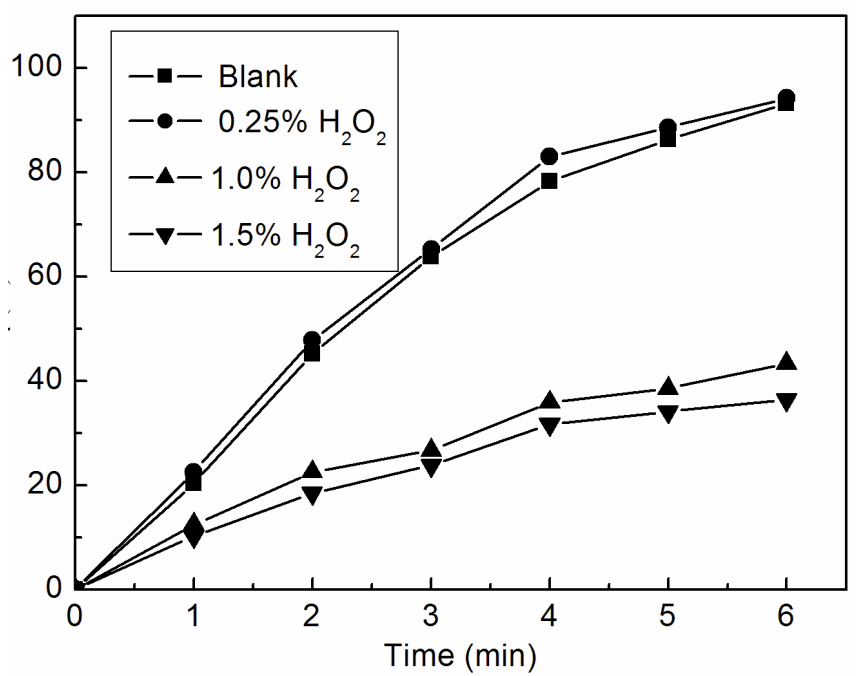

Fig. 6. Effect of $\mathrm{H}_{2} \mathrm{O}_{2}$ additive on naproxen degradation $\left(\mathrm{C}_{0}=20 \mathrm{mg} \mathrm{L}^{-1}\right.$, output power $=60 \mathrm{~W}$, air flow rate $=0.50 \mathrm{~m}^{3} \mathrm{~h}^{-1}$ )

Effect of $\mathrm{Fe}^{2+}$ additive on degradation of naproxen: $\mathrm{Fe}^{2+}$ has an evidently catalytic effect and the effect is more remarkable when the concentration of $\mathrm{Fe}^{2+}$ is higher ${ }^{30}$. The effect of $\mathrm{Fe}^{2+}$ as the additive on naproxen degradation by DBD was tested (Fig. 7). The results showed that the degradation efficiency of naproxen increased dramatically with the presence of $\mathrm{Fe}^{2+}$. When the concentration of $\mathrm{Fe}^{2+}$ was $40 \mathrm{mg}$ $\mathrm{L}^{-1}$, the total disappearance of naproxen was achieved at $2 \mathrm{~min}$, however only $70.8 \%$ of naproxen disappeared when $\mathrm{Fe}^{2+}$ was added at $120 \mathrm{mg} \mathrm{L}^{-1}$. These results indicated that an appropriate amount of $\mathrm{Fe}^{2+}$ could largely enhance the degradation of

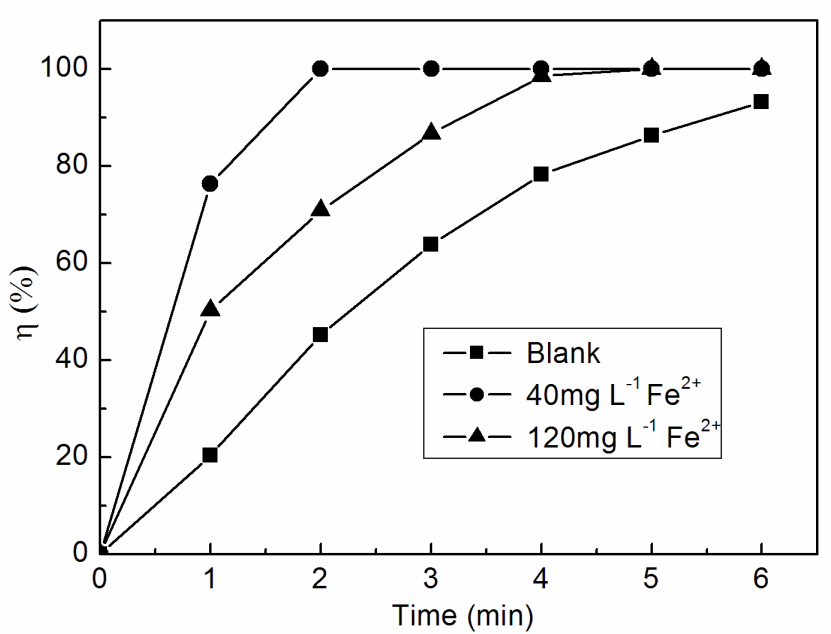

Fig. 7. Effect of $\mathrm{Fe}^{2+}$ additive on naproxen degradation $\left(\mathrm{C}_{0}=20 \mathrm{mg} \mathrm{L}^{-1}\right.$, output power $=60 \mathrm{~W}$, air flow rate $=0.50 \mathrm{~m}^{3} \mathrm{~h}^{-1}$ )

naproxen by DBD. The reason was that the appropriate amount of $\mathrm{Fe}^{2+}$ additive enhanced the oxidizing power of $\mathrm{H}_{2} \mathrm{O}_{2}$ because of the production of ${ }^{\circ} \mathrm{OH}$ in the solution (eqn. 12). Furthermore, the regeneration of $\mathrm{Fe}^{2+}$ from additional reduction of $\mathrm{Fe}(\mathrm{OH})^{2+}$ benefited the production of ${ }^{\circ} \mathrm{OH}$ (eqns. 13 and 14 ), hence, naproxen degradation process was enhanced. When the concentration of $\mathrm{Fe}^{2+}$ was high, it could compete with naproxen for ${ }^{\bullet} \mathrm{OH}$ (eqn. 15) and therefore the enhancement effect was accordingly weakened ${ }^{31,32}$.

$$
\begin{aligned}
& \mathrm{Fe}^{2+}+\mathrm{H}_{2} \mathrm{O}_{2} \rightarrow \mathrm{Fe}^{3+}+{ }^{\bullet} \mathrm{OH}+\mathrm{OH}^{-} \\
& \mathrm{Fe}^{3+}+\mathrm{OH}^{-} \rightarrow \mathrm{Fe}(\mathrm{OH})^{2+} \\
& \mathrm{Fe}(\mathrm{OH})^{2+}+\mathrm{hv} \rightarrow \mathrm{Fe}^{2+}+{ }^{\bullet} \mathrm{OH} \\
& \mathrm{Fe}^{2+}+{ }^{\bullet} \mathrm{OH} \rightarrow \mathrm{Fe}^{3+}+\mathrm{OH}^{-}
\end{aligned}
$$

Effect of $\mathrm{NO}_{3}{ }^{-}$additive on degradation of naproxen: Fig. 8 shows the effect of $\mathrm{NO}_{3}{ }^{-}$additive on the degradation of naproxen. The result showed that $\mathrm{NO}_{3}{ }^{-}$could enhance the degradation of naproxen, the degradation efficiency increased with the increasing concentration of $\mathrm{NO}_{3}{ }^{-}$. When the concentrations of $\mathrm{NO}_{3}^{-}$were 2 and $5 \mathrm{mg} \mathrm{L}^{-1}$, the degradation efficiency of naproxen were 92.8 and $100 \%$ at the discharge time of 5 min, but only $86.3 \%$, in the absence of $\mathrm{NO}_{3}^{-}$. The reason was that more ${ }^{\circ} \mathrm{OH}$ were produced in the presence of $\mathrm{NO}_{3}{ }^{-}$ (eqns. 16-18) ${ }^{33}$.

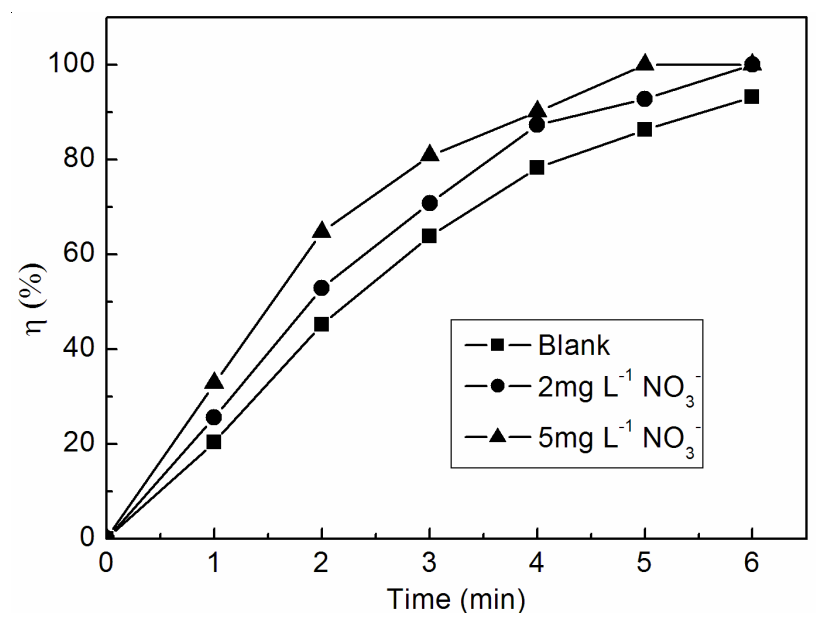

Fig. 8. Effect of $\mathrm{NO}_{3}{ }^{-}$additive on naproxen degradation $\left(\mathrm{C}_{0}=20 \mathrm{mg} \mathrm{L}^{-1}\right.$, output power $=60 \mathrm{~W}$, air flow rate $=0.50 \mathrm{~m}^{3} \mathrm{~h}^{-1}$ ) 


$$
\begin{gathered}
\mathrm{NO}_{3}^{-} \stackrel{\mathrm{hv}}{\longrightarrow}\left[\mathrm{NO}_{3}^{-}\right]^{*} \\
{\left[\mathrm{NO}_{3}^{-}\right]^{*} \longrightarrow \mathrm{NO}_{2}^{-}+\mathrm{O}^{\bullet} \longrightarrow \mathrm{NO}_{2}+\mathrm{e}_{\mathrm{aq}}^{-}+\mathrm{O}^{\bullet}} \\
{\left[\mathrm{NO}_{3}^{-}\right]^{*} \longrightarrow \mathrm{NO}_{2}+\mathrm{O}^{-} \stackrel{\mathrm{H}_{2} \mathrm{O}}{\longrightarrow}{ }^{\bullet} \mathrm{NO}_{2}+{ }^{\bullet} \mathrm{OH}+{ }^{\bullet} \mathrm{OH}}
\end{gathered}
$$

Effect of humic acid additive on degradation of naproxen: Results obtained when humic acid was added are shown in Fig. 9. In the presence or absence of humic acid additive, naproxen degradation efficiency increased with the increasing of discharge time. The degradation efficiency increased with the increasing concentratios of humic acid. When the concentrations of humic acid were 2 and $4 \mathrm{mg} \mathrm{L}^{-1}$, the degradation efficiency of naproxen were 90.5 and $97.4 \%$ at the discharge time of 5 min, but only $86.3 \%$ in the absence of humic acid. The reason was that humic acid could absorb light and generate excited triplet states $\left({ }^{3} \mathrm{HA} *\right)$ and various reactive oxygen species, including hydroxyl radicals $\left({ }^{\circ} \mathrm{OH}\right)$, singlet oxygen $\left({ }^{1} \mathrm{O}_{2}\right)$ and hydrogen peroxide $\left(\mathrm{H}_{2} \mathrm{O}_{2}\right)^{34}$, so the radical concentrations for reaction with naproxen increased.

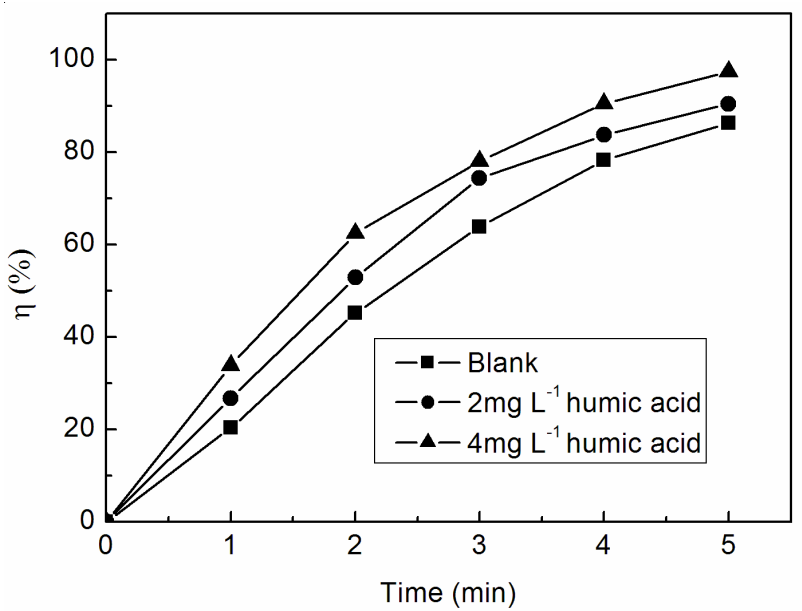

Fig. 9. Effect of humic acid additive on naproxen degradation $\left(\mathrm{C}_{0}=20 \mathrm{mg}\right.$ $\mathrm{L}^{-1}$, output power $=60 \mathrm{~W}$, air flow rate $=0.50 \mathrm{~m}^{3} \mathrm{~h}^{-1}$ )

Variation of solution $\mathbf{p H}$ value: The effect of $\mathrm{DBD}$ on $\mathrm{pH}$ value is shown in Fig. 10. It was noteworthy that the $\mathrm{pH}$ value decreased with the increasing of discharge time, $\mathrm{pH}$ values decreased from 6.62 to $5.12,6.41,6.18,5.78,5.53$ and 5.34 at the discharge time of 1,2,3,4 and 5 min. The decrease of $\mathrm{pH}$ values was possibly due to a large amount of $\mathrm{H}_{3} \mathrm{O}^{+}$ produced during degradation process.

Variation of solution TOC: Fig. 11 shows the change of TOC value of naproxen aqueous solutions. The solution TOC value decreased with the increasing of discharge time, which indicated that DBD could lead to both degradation and partial mineralization of naproxen in aqueous solutions.

Identification of degradation products: In order to optimize the instrumental parameters, a full-scan ESI mass spectrum of naproxen (negative ions) is reported in Fig. 12. The $[\mathrm{M}]^{-}$(m/z 228.8) ion was clearly observed in the spectrum, along with the corresponding isotope peak. Fragmentation of deprotonated naproxen in the ion source leads to the formation of two main product ions, arising from the loss of $\mathrm{CO}_{2}$ $(\mathrm{m} / \mathrm{z} 184.9)$ and the consecutive losses of $\mathrm{CO}_{2}$ and $\mathrm{CH}_{3}(\mathrm{~m} / \mathrm{z}$ 169.9).

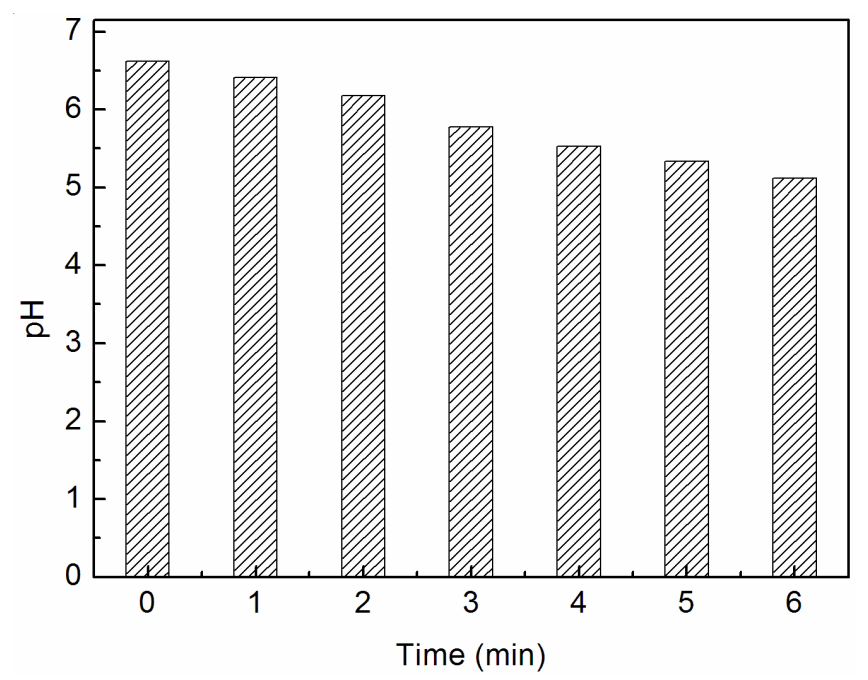

Fig. 10. Change of $\mathrm{pH}$ value of naproxen solution $\left(\mathrm{C}_{0}=20 \mathrm{mg} \mathrm{L}^{-1}\right.$, output power $=60 \mathrm{~W}$, air flow rate $=0.50 \mathrm{~m}^{3} \mathrm{~h}^{-1}$ )

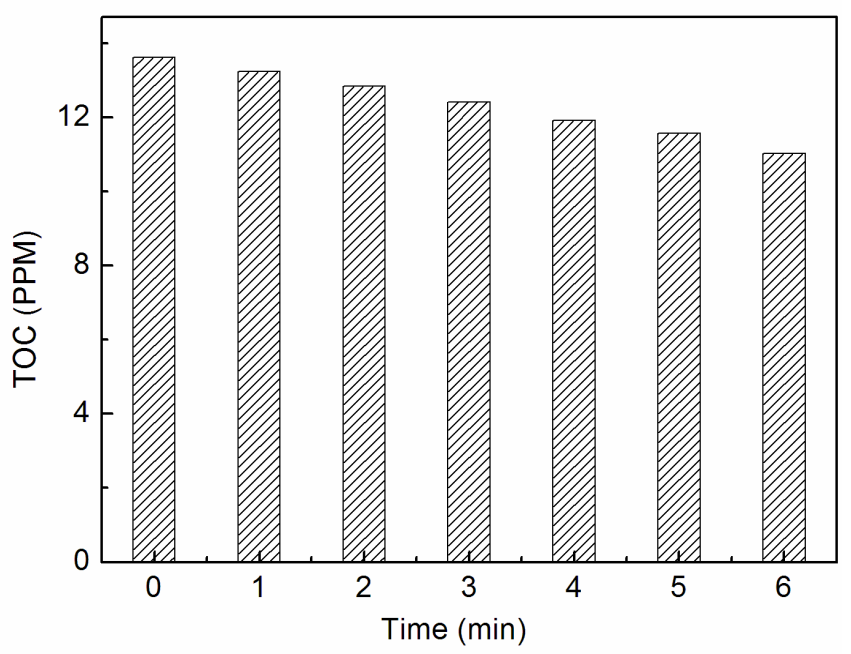

Fig. 11. TOC value variations of naproxen solution $\left(\mathrm{C}_{0}=20 \mathrm{mg} \mathrm{L}^{-1}\right.$, output power $=60 \mathrm{~W}$, air flow rate $=0.50 \mathrm{~m}^{3} \mathrm{~h}^{-1}$ )

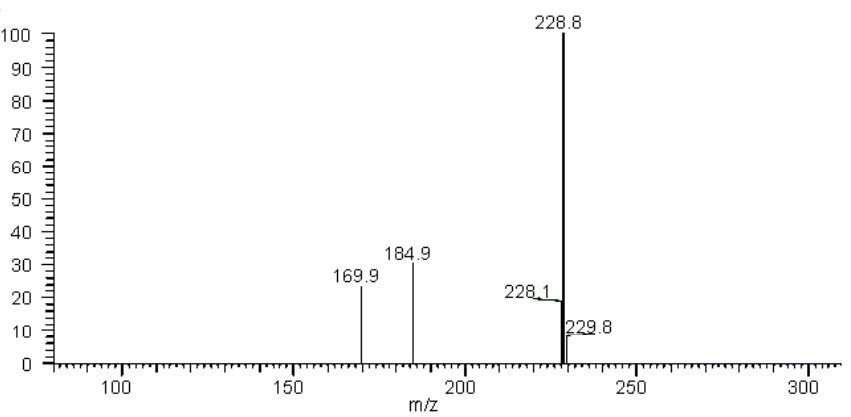

Fig. 12. Full-scan ESI mass spectrum of naproxen (negative ions)

According to Figs. 13 and 14, the major molecular ion $\left([\mathrm{M}]^{-}\right)$correlated with the degradation of naproxen by DBD was $\mathrm{m} / \mathrm{z}$ ions 213.9 and $184.9,15$ and $44 \mu$ lower than the naproxen ion, indicated that the demethylation and decarboxylation reaction generated by DBD. The possible degradation pathway of naproxen by DBD is shown in Fig. 15.

\section{Conclusion}

DBD could effectively degrade naproxen in aqueous solutions. The degradation efficiency was $93.2 \%$ when the output 


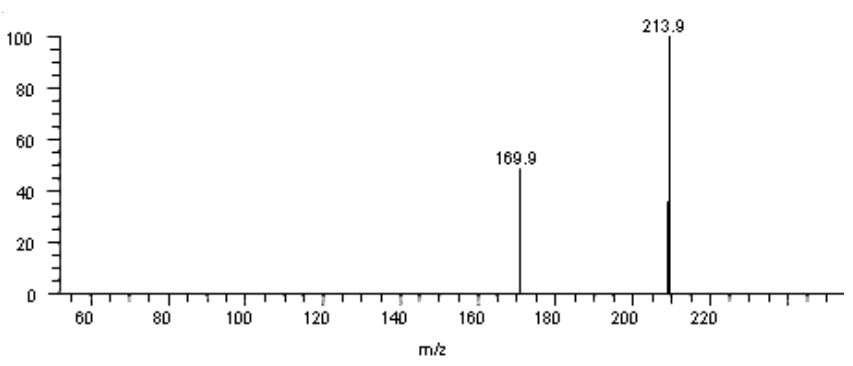

Fig. 13. Full-scan ESI mass spectrum of the $\mathrm{m} / \mathrm{z}$ ion 213.9

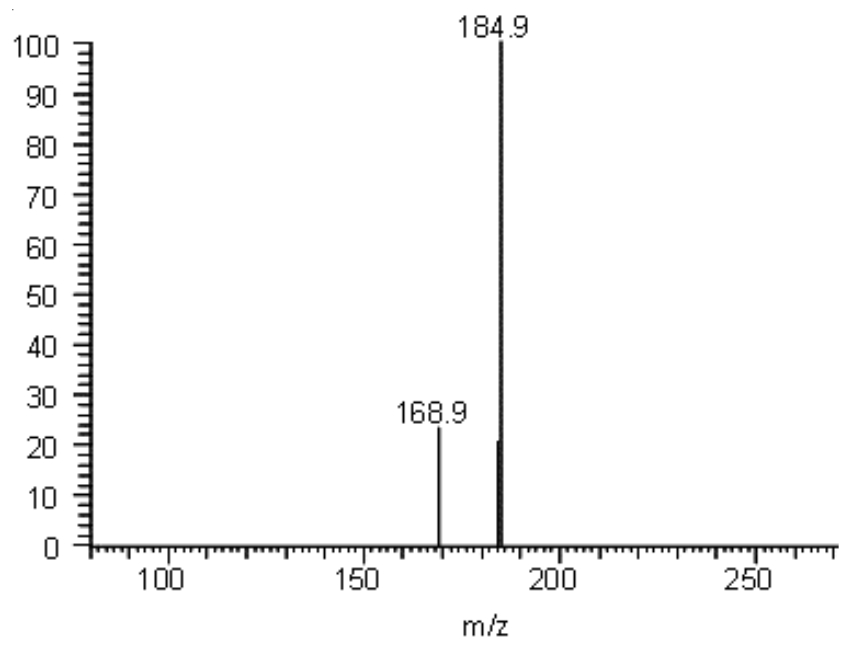

Fig. 14. Full-scan ESI mass spectrum of the $\mathrm{m} / \mathrm{z}$ ion 184.9<smiles>CC(C(=O)O)c1ccc2cc(O)ccc2c1</smiles><smiles>[CH]c1ccc2cc([C@@H](C)OC(=O)C(C)c3ccc4cc(OC)ccc4c3)ccc2c1</smiles>

Fig. 15. Possible degradation pathway of naproxen by DBD

power was $60 \mathrm{~W}$ and 6 min was selected as the discharge time. The degradation reaction of naproxen followed first-order like kinetics.

The $\mathrm{pH}$ value affected the naproxen degradation process. The degradation yield was higher under acidic conditions than in alkaline media. Naproxen degradation efficiency decreased with the increase of initial concentration. $\mathrm{H}_{2} \mathrm{O}_{2}$ as the additive enhanced the degradation process at the concentration of $0.25 \%$, however, hindered the degradation at 1.0 and $1.5 \%$. $\mathrm{Fe}^{2+}$ benefited the degradation at $40 \mathrm{mg} \mathrm{L}^{-1}$, however, the enhancement effect was weakened when $\mathrm{Fe}^{2+}$ was added at $120 \mathrm{mg} \mathrm{L}^{-1}$. $\mathrm{NO}_{3}{ }^{-}$and humic acid additives also enhanced the degradation of naproxen. The $\mathrm{pH}$ value and TOC of naproxen solution decreased with the increasing of discharge time. The possible degradation pathway of naproxen was demethylation and decarboxylation reaction.

\section{ACKNOWLEDGEMENTS}

The authors gratefully acknowledged the support from major project on Control and Rectification of Water Body Pollution, P.R. China (Foundation item No. 2008ZX07101004). Thanks are also due to Qun Liu and Weiping Wang for their help in the experimental work.

\section{REFERENCES}

1. B. Halling-Sorensen, S.N. Nielsen, P.F. Lanzky, F. Ingerslev, H.C.H. Lutzhoft and S.E. Jorgensen, Chemosphere, 36, 357 (1998).

2. T.A. Ternes, N. Herrmann, M. Bonerz, T. Knacker, H. Siegrist and A. Joss, Water Res., 38, 4075 (2004).

3. C.E. Rodríguez-Rodríguez, E. Marco-Urrea and G. Caminal, Bioresour. Technol., 101, 2259 (2010).

4. N. Nakada, T. Tanishima, H. Shinohara, K. Kiri and H. Takada, Water Res., 40, 3297 (2006)

5. J. Radjenovic, A. Jelic, M. Petrovic and D. Barcelo, Anal. Bioanal. Chem., 393, 168 (2009)

6. J. Radjenovic, M. Petrovic and D. Barceló, Anal. Bioanal. Chem., 387, 1365 (2007).

7. M.J. Benotti, R.A. Trenholm, B.J. Vanderford, J.C. Holady, B.D. Stanford and S.A. Snyder, Environ. Sci. Technol., 43, 597 (2009).

8. E. Marco-Urrea, M. Pérez-Trujillo, P. Blánquez, T. Vicent and G. Caminal, Bioresour. Technol., 101, 2159 (2010).

9. J.L. Zhao, G.G. Ying, L. Wang, J.F. Yang, X.B. Yang, L.H. Yang and X. Li, Sci. Total Environ., 407, 962 (2009).

10. X. Zhao, J.H. Qu, H.J. Liu, Z.M. Qiang, R.P. Liu and C.Z. Hu, Appl. Catal. B, 91, 539 (2009).

11. F. Gagné, C. Blaise, M. Fournier and P.D. Hansen, Biochem. Phys. C, 143, 179 (2006).

12. G.R. Boyd, S.Y. Zhang and D.A. Grimm, Water Res., 39, 668 (2005).

13. N. Nakada, H. Shinohara, A. Murata, K. Kiri, S. Managaki, N. Sato and H. Takada, Water Res., 41, 4373 (2007).

14. V.J. Pereira, K.G. Linden and H.S. Weinberg, Water Res., 41, 4413 (2007).

15. J.M. Poyatos, M.M. Munio, M.C. Almecija, J.C. Torres, E. Hontoria and F. Osorio, Water Air Soil Pollut., 205, 187 (2010).

16. C.E. Rodriguez-Rodriguez, E. Marco-Urrea and G. Caminal, J. Hazard. Mater., 179, 1152 (2010)

17. X.J. Xu, Thin Solid Films, 390, 237 (2001).

18. N. Sano, T. Kawashima and J. Fujikawa, Ind. Eng. Chem. Res., 41, 5906 (2002).

19. R. Peyrous, P. Pignolet and B. Held, J. Phys. D; Appl. Phys., 22, 1658 (1989).

20. B. Eliasson, M. Hirth and U. Kogelschatz, J. Phys. D: Appl. Phys., 20, 1421 (1987).

21. F. Abdelmalek, M.R. Ghezzar and M. Belhadj, Ind. Eng. Chem. Res., 45, 23 (2006)

22. A. Yabe, Y. Mori and K. Hijikata, AIAA J., 16, 340 (1978).

23. J.W. Feng, Z. Zheng, J.F. Luan, K.Q. Li, L.H. Wang and J.F. Feng, J. Hazard. Mater., 164, 838 (2009).

24. H.J. Wang, J. Li and X. Quan, J. Electrostat., 64, 416 (2006).

25. A.A. Joshi, B.R. Locke and P. Arce, J. Hazard. Mater., 41, 3 (1995).

26. K. Gai, J. Hazard. Mater., 146, 249 (2007).

27. B. Sun, M. Sato and J.S. Clements, Environ. Sci. Technol., 34, 509 (2000).

28. D.W. Hu and C.C. Cheng, Chongqing Environ. Sci., 3, 34 (1999) (in Chinese).

29. L. Chen, Y.X. Du and L.C. Lei, Environ. Sci., 5, 106 (2003) (in Chinese).

30. J. Gao, L. Pu, W. Yang, J. Yu and Y. Li, Plasma Process. Polym., 1, 171 (2004).

31. Y. Sun and J.J. Pignatello, Environ. Sci. Technol., 2, 304 (1993).

32. C. Flox, S. Ammar, C. Arias, E. Brillas, A.V. Vargas-Zavala and R. Abdelhedi, Appl. Catal. B, 67, 93 (2006).

33. P.L. Brezonik and J. Fulkerson-Brekken, Environ. Sci. Technol., 32, 3004 (1998).

34. S.H. Sandvik, P. Bilski, J.D. Pakulski, C.F. Chignell and R.B. Coffin, Mar. Chem., 69, 139 (2000). 